
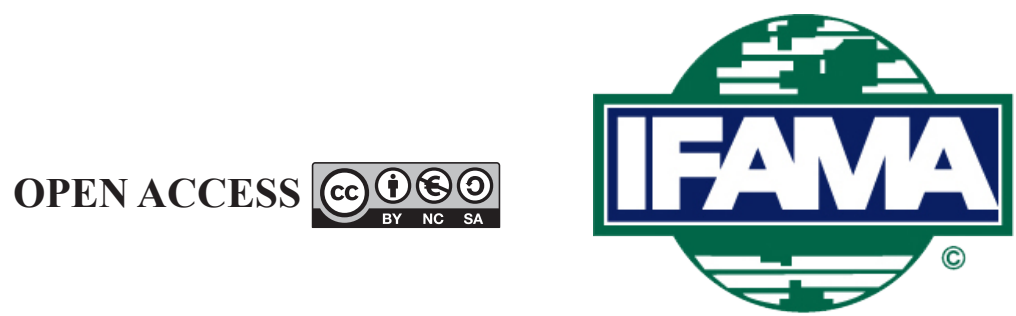

International Food and Agribusiness Management Review

Volume 25, Issue 1, 2022; DOI: 10.22434/IFAMR2021.0015

Received: 9 February 2021 / Accepted: 22 June 2021

\title{
Determinants of innovation by agri-food firms in rural Spain: an MCA PLS-SEM analysis
}

\section{RESEARCH ARTICLE}

\author{
Xosé-Manuel Martínez-Filgueira ${ }^{\mathrm{a}}$, David Peón ${ }^{\oplus \mathrm{b}}$ and Edelmiro López-Iglesias ${ }^{\mathrm{c}}$ \\ ${ }^{a}$ Full Professor, Department of Economics, University of A Coruna \\ (UDC), Campus Elviña s/n, 15071 A Coruña, Spain \\ ${ }^{b}$ Assistant Lecturer, Department of Business, University of A Coruna \\ (UDC), Campus Elviña s/n, 15071 A Coruña, Spain
}

${ }^{c}$ Full Professor, Department of Applied Economics, University of Santiago de Compostela (USC), Burgo das Nacións s/n, 15782 Santiago de Compostela, Spain

\begin{abstract}
The development of a sustainable rural world must have an innovative agri-food industry as one of its bases. This article offers a comprehensive analysis of the main drivers of innovation by small and medium agrifood companies in Spain. A combined multiple correspondence analysis (MCA) and structural equation modelling (PLS-SEM) is performed to identify the key factors among 63 indicators in the domains of the technology-organisation-environmental approach. The results suggest an open field of research. Positively related to innovation are firm capacities and financial resources. Moreover, agri-food firms innovate in products, processes or marketing in order to increase sales, enter new markets, or increase the quality of their products. On the contrary, most of these firms did not innovate to reduce costs or time of response, meet regulatory compliance or maintain employment. Authorities should be aware that smaller and younger agri-food firms face more restrictions to innovate, and firms feel public policies could help to meet market demand as a driving force of innovation. On the contrary, essential objectives of regional development such as environmental compliance and maintaining employment seem to depend solely on public action.
\end{abstract}

Keywords: innovation, rural SMEs, R\&D investment decisions, agri-food, MCA, PLS-SEM JEL code: O31, L21, C38

\footnotetext{
${ }^{\circledR}$ Corresponding author: david.peon@udc.es
} 


\section{Introduction}

Fostering entrepreneurship and business development in rural areas is a key target in the recent and future European Union strategy, and the agri-food industry is one of the most relevant sectors for this purpose. To help reverse the decline of rural areas, public policies can either encourage activities that take advantage of rural resources to market their products or services elsewhere, or help sustain local demand from residents, tourists and retirees - and the agri-food industry can operate with both approaches. Moreover, it should be a powerful lever for transformation towards a sustainable rural world, since it is the largest production industry in the European Union, both in terms of turnover and employment (Firlej et al., 2017).

Based on the above, authorities - e.g. Horizon Europe, European Research and Innovation Framework Programme 2021-2027 (European Commission, 2021) - and practitioners (e.g. European Commission, 2016b) recommend fostering innovation by firms based in rural areas. Innovation is an essential requirement for value creation; indeed, there is often a positive correlation of innovation and performance (Thornhill, 2006). However, success is not guaranteed: almost $50 \%$ of new products fail (Battor and Battor, 2010). The purpose of this article is to delve into the main drivers of investment in innovative activities by small and medium-sized (SME) agri-food companies.

The study of innovation drivers is a recurrent research topic. Withal, in the case of agribusinesses, most research has focused on specific topics, such as the adoption of information technologies (ICT). We contribute to the literature in two instances. First, we perform a comprehensive analysis, both on the innovation decisions by the agri-food firms being analysed and on the range of potential innovation drivers. On the one hand, we look at the four types of innovation decisions frequently measured: namely, innovation on products, on processes, organisational innovation and marketing innovation. On the other hand, using the technologyorganisation-environment approach (TOE) as conceptual framework, we analyse how a complete set of more than 60 variables in these domains influence innovation, with a focus on the capacities and financing constraints of the firms, the expected benefit of the new technology, and the market and social conditioning factors of innovation decisions by agri-food SMEs in rural areas.

The second contribution is methodological. We perform a combined statistical and econometric analysis that involves multiple correspondence analysis (MCA) and structural equation modelling (SEM). MCA is a statistical technique for multivariate analysis of categorical data, while the SEM model - here estimated by making use of the partial least squares (PLS) approach - is used to test a set of a priori hypotheses on the drivers of innovation. The reason for this combined approach is twofold. On the one hand, the database we use - the Spanish Technological Innovation Panel (PITEC), a complete annual survey to a large set of firms, here delimited to specific rural areas of Spain where socioeconomic indicators are weak - provides information where most variables are categorical, do not follow a common Lickert scale, and in some cases exhibit a high number of missing responses. Hence, MCA is applied to the list of categorical variables to obtain a single indicator per domain that summarises all information. Next, SEM-PLS uses as indicators of each domain the coordinates obtained through MCA. On the other hand, the stepwise process also allows to discard variables from the PITEC database that are not informative enough.

The article is structured as follows. In the next section we review the state of arts on the impact of weak capacities and weak financing on innovation by agri-food SMEs in rural areas. Section 3 deals with the conceptual framework on the determinants of innovation by SMEs in rural areas and develops the main hypotheses to be tested. Section 4 describes our sample and data collection procedure and describes the measurement of the variables of analysis. Section 5 implements the SEM analysis, and Section 6 provides a discussion of the main results, and concludes. Complete results and robustness tests are available in the Supplementary Material. 


\section{State of arts: weak capacities and weak financing for SME innovation}

\subsection{Entrepreneurship in rural areas}

Rural areas in the European Union (EU) continue to lag in socio-economic terms. Consequently, a key objective of the EU has been to promote entrepreneurship and small business development there. However, the rate of business start-ups is lower than in urban areas, and businesses are less likely to survive (Renski, 2009). Understanding the drivers of success and failure becomes essential, but business analysis in rural regions is yet underdeveloped (Besser and Miller, 2013; Peón et al., 2020; Quinn et al., 2013).

Public policies aimed at fostering business activities and entrepreneurship in rural areas may be developed in two alternative ways (Barbut, 2009): the 'productive economy', increasing the competitiveness of the local economy to sell goods and services outside the rural territory, and the 'residential economy', which seeks to create local jobs linked to increased local demand by residents, tourists, and retirees (European Commission, 2016a). The agri-food industry can combine both approaches since, being often mostly oriented to urban markets, it is one of the sectors that can contribute most to the creation of quality employment. There, we have seen a move in recent decades towards a discourse based on competitiveness (Erjavec et al., 2009). However, the environment for firms operating in rural areas is tougher, often facing drawbacks such as dealing with lower demand, less favourable ecosystems, worse infrastructure, and administrative burdens. These could be overcome by firms with characteristics that increase their potential, but often they have weaker innovation capacities, and lack of sufficient access to private and public capital. These drawbacks are summarised under the heading weak capacities and weak financing.

By capacities we refer to a firm's ability to achieve something successfully, while capacity development would be the process whereby firms create, maintain and strengthen capacity over time. Thus, weak capacities would include limited human capital resources, higher risk aversion of rural dwellers, weaker market power and less access to research results, among others (Erjavec and Rickson, 2016). In addition, under a resourcebased view, limited resources would include not only human capital, but physical and financial (e.g. Sehnem et al., 2016). Thus, under the weak financing literature we include any evidence of financial constraints and discouraged borrowing. Access to finance is a key challenge for the creation, survival and growth of SMEs (OECD, 2012); for firms in rural in particular, financing costs are higher in relative terms (OECD, 2018), and weak access to capital is a major barrier for rural entrepreneurs (e.g. Tampien, 2016).

\subsection{Innovation by agri-food firms in rural areas}

Innovation is defined by the EU Community Innovation Survey (CIS) as the introduction of a new or improved product, process, organisational or marketing method by a firm, implying newness of products, processes, or business practices (Johannessen et al., 2001). Innovation has been essential for the development of the agri-food industry (Zouaghi and Sanchez, 2016), particularly the investment in innovative products and processes (Batterink et al., 2006). Nonetheless, the analysis of innovation by rural firms - and agri-food SMEs in particular - is frequently limited to specific scopes.

A well-studied branch in the literature focuses on the determinants of adopting ICT technologies by farmbased companies (Sonawane, 2014; Turland and Slade, 2020). Avermaete et al. (2003) identify age and firm size as relevant for small food firms. A related branch analyses the determinants to invest in research and development (R\&D). The main barriers include costs (financial constraints), knowledge (e.g. lack of qualified personnel) and market factors (e.g. market power) (Blanchard et al., 2013). For such reason, SMEs often lack the resources to make the appropriate $R \& D$ investments, but they are still able to be innovative and, for the food industry in particular, marketing abilities play a key role (Banterle et al., 2011).

The analysis of other scopes is only more recent. Mirzaei et al. (2016) examine entrepreneurial and market orientation on product and marketing innovation in farm-based businesses in Canada. Díaz-Pichardo et al. 
(2017) show differences between urban and rural environments in business innovation processes in Mexico. Peón and Martínez-Filgueira (2020) perform an exploratory analysis on innovation decisions by small agrifood firms, and observe a distinctive behaviour of marketing innovation. In Spain, most recent research on innovation by agri-food firms is either descriptive, focused on a specific local area, or lacks a global scope of analysis on the determinants of innovation. Among the most consistent results, we may highlight the positive impact of firm's size and age, the positive impact of managerial and corporate culture, and that cooperatives tend to be more innovative (Corchuelo and Mesías, 2017; Corchuelo et al., 2020; Fearne et al., 2013). Moreover, the main factors hindering innovation for agri-food SMEs relative to large firms include high costs of innovation and lack of internal and external financing (Arias et al., 2016), while other relevant restrictions would be lack of human resources, difficulties to cooperate with other firms, and lack of technological or market information (Arias et al., 2016; Corchuelo and Ferreiro, 2019). Finally, some authors find that in certain Spanish regions the location of firms in the rural/urban divide does not have any impact on innovation (Fearne et al., 2013), contrary to what is found in other regions (Castillo and García, 2016), but commuting facilities do have a positive effect (García Álvarez-Coque et al., 2013). The purpose of the study that follows is to contribute to this literature with a comprehensive analysis and at a larger scale.

\section{Conceptual framework and hypotheses development}

We use TOE as conceptual framework, a multi-perspective organisation-level approach that explains how the technological, organisational, and environmental contexts influence innovations (Baker, 2011). Thus, innovation determinants may be internal, such as CEO traits and characteristics of the firm, and external, including the characteristics of the technology and the environment (Ramayah, 2016). Some frequent domains across industries are identifiable. In this section, we pose the hypotheses that will be tested, following the most frequent domains in the literature, and the set of variables to be analysed.

The organisational context includes managers and business characteristics. These on one hand include managers' age, education, and income, as well as their attitudes (perceived benefits of the innovation, support, and readiness to implement it). On the other hand, we have firms' size (number of employees, capital base), farm attributes (size, crops) and business orientation. Some authors also include facilitating conditions and (ICT usage) habit (Adamkolo et al., 2016; Agwu et al., 2008; Ali, 2012; Alvarez and Nuthall, 2006; Tiffin and Balcombe, 2011). Regarding external factors, the TOE approach separates technological and environmental characteristics. Thus, innovation features have a critical role, which depends on the expected benefits in terms of productivity (Maduku et al., 2016). Common factors include cost, relative advantage, security, perceived usefulness, and complexity. Finally, environmental factors include the degree of competition in the industry, value chain partners and institutional partners (e.g. universities).

Following this literature, we pose a series of propositions for the main determinants of innovation by agrifood firms in rural areas, which are to be validated through the reliability analysis of the measurement model. They follow in order next.

Organisation. Propositions referring either to the managers or to the firm itself.

- P1: CEO support has a positive impact on agri-food SMEs innovation.

- P2: Firm size has a positive impact on agri-food SMEs innovation.

- P3: Availability of financial resources has a positive impact on agri-food SMEs innovation. 
Technology. Propositions referred to the characteristics of the intended innovation. On one hand, some of them refer the expected benefit of the technology to be implemented.

- P4a: The expected benefit of technology in terms of company growth has a positive impact on agrifood SMEs innovation.

- P4b: The expected benefit of technology in terms of new markets and customer segments has a positive impact on agri-food SMEs innovation.

- P5a: The expected benefit of technology in terms of increasing quality has a positive impact on agri-food SMEs innovation.

- P5b: The expected benefit of technology in terms of reducing costs has a positive impact on agrifood SMEs innovation.

- P5c: The expected benefit of technology in terms of reducing time of response has a positive impact on agri-food SMEs innovation.

- P6a: The expected benefit of technology in terms of regulatory compliance has a positive impact on agri-food SMEs innovation.

- P6b: The expected benefit of technology in terms of employment has a positive impact on agri-food SMEs innovation.

On the other hand, some others refer to the complexity of developing or adopting such technology.

- P7: The complexity of adopting the innovation has a negative impact on agri-food SMEs innovation.

Environmental. Propositions referred to external factors in three domains:

- P8: Competitive pressure has significant impact on agri-food SMEs innovation.

Here we do not claim an ex-ante positive or negative impact of the degree of competition on innovation, since two opposite views are observed in the literature (Rodriguez et al., 2017): a negative one (Schumpeterian view), versus the interpretation of competition fostering innovation (Arrovian view).

- P9: Value chain support has a positive impact on agri-food SMEs innovation.

- P10: Social influence has a positive impact on agri-food SMEs innovation.

Now, we pose the key hypotheses to be tested, referred to the latent constructs that will be defined as compositions of the previous domains. Here we follow Peón and Martínez-Filgueira (2020) analysis on innovation decisions by small agri-food firms. Their exploratory results suggest that the basic latent variables to be tested in a structural equation model should include, tentatively, three: namely, the internal characteristics of the firm that condenses its willingness or ability to innovate; a construct for the perceived advantages of innovation, related to the main objectives why firms innovate; and external restrictions to innovate, which would condense either financial or technological restrictions, as well as competitive disadvantage. These hypotheses to be tested through the SEM-PLS analysis. They follow in order.

H1: The firm's ability to innovate has a significant positive impact on agri-food SMEs innovation.

H2: The perceived advantages of innovation have a significant positive impact on agri-food SMEs innovation.

H3: The external restrictions to innovate have a significant negative impact on agri-food SMEs innovation.

The hypothesised research framework, which summarises all propositions and hypotheses above, is shown in Figure 1. 


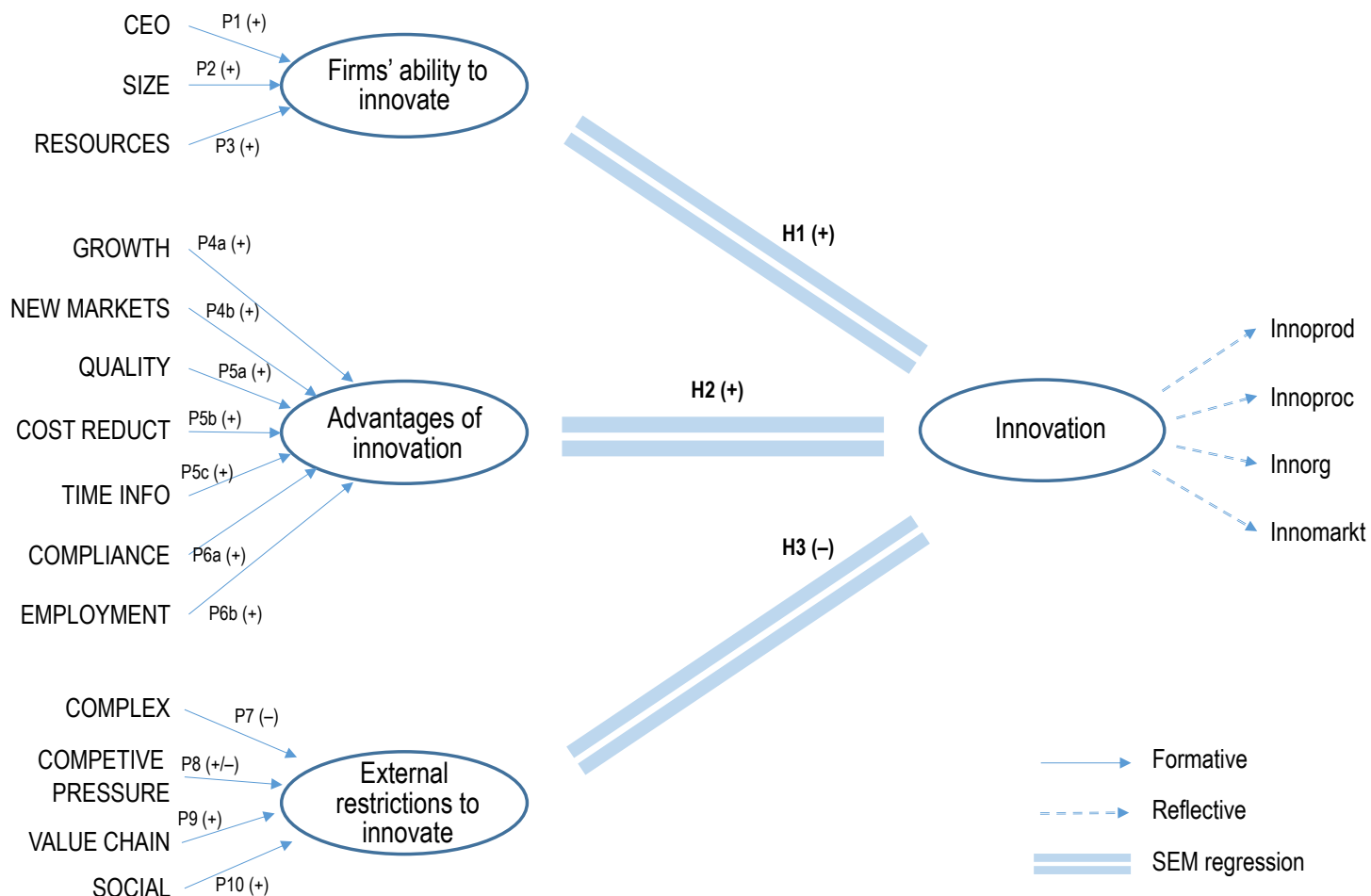

Figure 1. Hypothesised research framework.

\section{Sample and data: measurement}

\subsection{Data collection procedure and sample}

The research uses data from the PITEC database on innovation decisions by a large set of Spanish firms. ${ }^{1}$ In terms of regional scope, we analyse the NUTS 3 regions in Spain (provinces) that are rural or intermediate, following the urban-rural typology developed by Eurostat, ${ }^{2}$ and belong to NUTS 2 regions (Autonomous Regions) in mainland Spain where all provinces are rural or intermediate. This results in 24 provinces in the Autonomous Regions of Asturias (1), Cantabria (1), Castilla y León (CyL) (9), Castilla-la-Mancha (CLM) (5), Extremadura (2), Galicia (4), La Rioja (1) and Navarra (1) - see the shadowed area in Figure 2.

With $276,000 \mathrm{~km}^{2}$ and 10.95 million inhabitants in 2015, representing more than half $(54.6 \%)$ the size of Spain but less than a quarter $(23.6 \%)$ of its population, the area considered is overall a paradigmatic case of demographic decline: it shows a low density (39.7 vs 91.8 inhab $/ \mathrm{km}^{2}$ of Spain, driven by CyL, CLM and Extremadura's densities below $30 \mathrm{inhab} / \mathrm{km}^{2}$ ), the average age of the population is three years higher than Spain (45.2 vs 42.7), and fertility rate in some of these NUTS 2 regions is among the lowest in Europe (e.g. 1.04 children per woman in Asturias and 1.12 in Galicia in 2016, versus 1.34 of Spain, and 1.58 of EU-28 in year 2015). Finally, it also lags in economic performance: the GDP per capita (22,200 Euros by 2017) was $89 \%$ the Spanish average. ${ }^{3}$

\footnotetext{
${ }^{1}$ The PITEC database is publicly available, as well as the methodology (in English), the complete set of questionnaires and how variables are defined (these two in Spanish only) at: https://services.icono.fecyt.es/PITEC/Paginas/descarga_bbdd.aspx

$2 \mathrm{https} / / /$ ec.europa.eu/eurostat/statistics-explained/index.php?title=Territorial_typologies_manual__urban-rural_typology

${ }^{3}$ Data sources: Instituto Nacional de Estadística (INE, Madrid, Spain) and Eurostat (EU, Brussels, Belgium).
} 


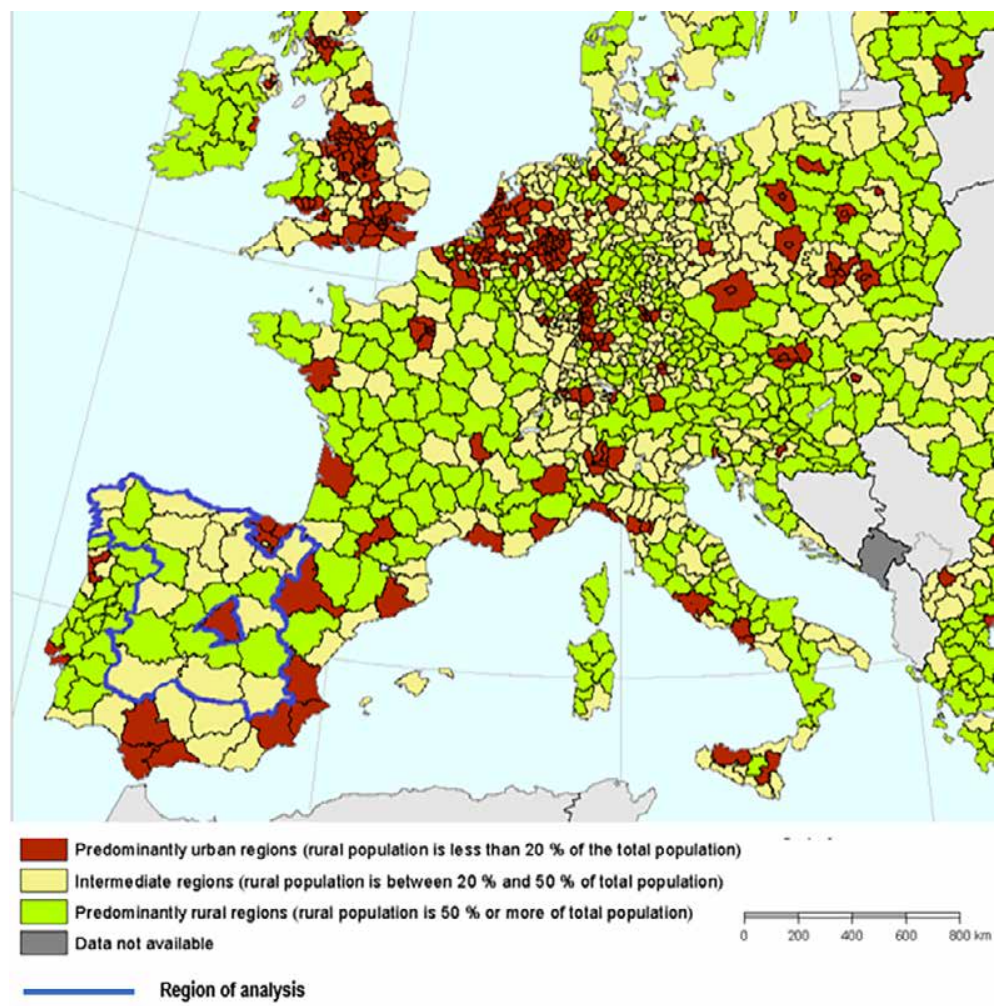

Figure 2. Urban-rural typology for NUTS level 3 regions (Eurostat, 2020).

In terms of sectoral analysis, we focus on the agri-food industry. PITEC replaces the International Standard Industrial Classification (ISIC) codes with 44 aggregated divisions. Thus, we define the agri-food industry as including the following divisions (Zouaghi and Sánchez, 2016):

- Agriculture, cattle, forestry, and fishing (divisions 1, 2 and 3 of ISIC Rev. 4).

- Food, beverages, and tobacco (divisions 10, 11 and 12).

We make use of a pooled data set of innovation investments by the firms over the last three years during the period 2010 to $2014,{ }^{4}$ what implies having data about real innovation decisions over a series of seven years and avoids the statistical inconvenience of having a small sample of subjects in the industries and rural areas of analysis. We retrieve any firms in the PITEC database classified as 'with no incidents' (i.e. excluding merged, absorbed, closed and other non-existing firms), and we filter as cases of study any companies with more than $50 \%$ of their personnel in R\&D activities set in the Autonomous Regions of analysis. Finally, we keep only independent companies, and filter out firms with zero or negative revenues. ${ }^{5}$ We end up with 283 firms, distributed by regions as provided in Table 1.

\footnotetext{
${ }^{4}$ We use five years of pooled data, which suffices for such statistical analysis, and larger periods may be susceptible to structural changes. Withal, seeking to enlarge the sample would be limited by data available in the PITEC database: first, there is only sufficient data available until year 2015 (and the number of firms was substantially reduced after 2014); second, there are a large set of variables (e.g. organisation and marketing innovation, variables object_i and gradorg_i on the objectives of innovation, etc.) that were included and are only available after 2008.

${ }^{5}$ Anonymised variables in the PITEC database include revenues, number of employees, staff in R\&D activities, and total investment in physical goods and in innovation. Following the INE, using these data is suitable for most statistical and econometric research, since the anonymisation techniques - ranking and grouping observations to obtain average data - lead to 'small biases in any case' (source: PITEC methodological note, available at: http://www.ine.es/prodyser/microdatos/metodologia_pitec.pdf). Moreover, since we only transform numerical (anonymised) variables into quartiles, any potential biases are avoided.
} 
Table 1. Regional distribution of sample observations.

\begin{tabular}{llllllllll}
\hline $\begin{array}{l}\text { Agri-food } \\
\text { companies }\end{array}$ & Region & & & & & & Total \\
\cline { 2 - 8 } & Asturias & Cantabria & CyL & CLM & $\begin{array}{l}\text { Extrema- } \\
\text { dura }\end{array}$ & Galicia & Navarra & Rioja & \\
\hline $\mathrm{n}$ & 0 & 5 & 76 & 18 & 50 & 52 & 47 & 35 & 283 \\
$\%$ & 0.0 & 1.8 & 26.9 & 6.4 & 17.7 & 18.4 & 16.6 & 12.4 & 100.0 \\
\hline
\end{tabular}

\subsection{Measurement}

We select variables in PITEC database in two instances: the decisions to innovate by the firms, and the determinants of innovation. The list of variables and a descriptive summary are provided in Supplementary Table S1.

Innovation variables. PITEC provides firms' answers to the survey regarding the four types of innovation decisions defined by the CIS: products, processes, organisational and marketing methods. Thus, we know whether any company declares to take innovative actions of four kinds:

- Innovation on products (innoprod) includes innovation in goods or services.

- Innovation on processes (innoproc) considers innovation in production methods, logistics, and support to processes.

- Innovation on organisation (innorg), whether on management systems, work organisation or external relationships.

- Marketing innovation (innomarkt), whether on product design, distribution channels, market targeting or price strategy.

All variables in the four innovation domains are defined as 0-1 dummies.

Then, following TOE in Section 3, the determinants of innovation are grouped in three areas:

Organisation. It includes internal variables referring either to the managers or to the firm itself.

- Managers (CEO): we include measures on the manager support, or propensity to act, and perceived benefits (performance expectations).

- Firm: measures of firm size (SIZE), and whether financial resources are available (RESOURCES). Business type, another classic in the literature, is acknowledged by analysing agri-food firms in particular.

Technology. It includes external factors referred to the characteristics of the intended innovation:

- Expected benefit: it considers variables in the PITEC database that measure the perceived usefulness in terms of increasing sales (GROWTH, NEW MARKETS) and product quality (QUALITY), reducing costs (COST REDUCT), maintaining employment (EMPLOYMENT), and improving internal processes (COMPLIANCE, TIME INFO), among others.

- Complexity (COMPLEX): it refers to the difficulty of developing or adopting the technology, including the type of research required.

Environmental. External factors as well, they refer to variables in three domains:

- Competitive pressure: to trace evidence of either a positive or a negative relationship between innovation and degree of competition.

- Value chain: customer pressure to improve goods and services, and facilitating conditions by suppliers.

- Social influence (SOCIAL): institutional partners and any other sources of information to innovate. 
With only a few numerical exceptions (Supplementary Table S1), most variables are defined by PITEC as categorical variables with four values: $1=$ high; $2=$ intermediate; $3=$ low; $4=$ not relevant/not used. Being most of them categorical variables, together with the fact that they do not follow the traditional 5-degrees Lickert scale, an additional step needs to be implemented prior to testing the SEM-PLS model. This step is multiple correspondence analysis (MCA).

\subsection{Multiple correspondence analysis}

MCA is a multivariate statistical technique to analyse categorical data, exploring the relationship between categorical variables that are at the same level (i.e. none of them are considered to be dependent or causal), by reducing the dimensionality of data based on the chi-square distance rather than linear correlations or Euclidean distances (Greenacre, 2016).

MCA is applied to the list of categorical variables in each domain, to obtain a single indicator per domain that summarises all information provided by the variables. We do it in three steps. First, numerical variables were transformed into quartiles. Then, for the sake of interpretation - since the rank of the categorical variables in the PITEC database is ascending (from $1=$ 'high relevance' to $4=$ 'not relevant') - they were recoded inversely. Only three of them were not recoded, for coherence with the domains they are included.

Second, we use Cronbach alpha to check that the variables we assumed to fall within a specific domain are indeed related. We accept domains whenever alpha is greater than 0.7. Otherwise, we eliminate the worst variable, and accept the domain if alpha is greater than 0.6 or exclude the domain. The complete results are provided in Supplementary Table S2. This way, we tested that all domains make sense, with the nuance of domains 'competitive pressure' and 'value chain', which we opted to merge in a single domain - now called COMPETITION, as it inversely relates to the bargaining power of the firm against its competitors and stakeholders in the value chain.

Third, MCA is implemented. To that purpose, we determine the dimension whose coordinates are to be used as indicator of each domain in the SEM analysis, and we interpret their sign. Missing values are replaced by average data, as standard in the package FactoMineR (Le et al., 2008). The selected dimension is the one that ranks variables in that specific domain in a coherent manner - which is usually the one with the highest proportion variance explained. The only exceptions are domains COMPLIANCE and EMPLOYMENT, for which the second domain was selected. In addition, coordinates were inverted for eight domains for the sake of interpretation of results in the subsequent SEM analysis.

\section{Data analysis}

\subsection{Descriptive statistics}

The main descriptive statistics of the MCA indicators - which are the coordinates to be used in the SEM that follows next - are provided in Table 2. Since the results of MCA are standardised, the mean values of all indicators are normalised to zero. The standard deviations range from 0.49 , the lowest for TIME INFO (improving organisation characteristics to reduce the time of response and enhancing information exchange), to 0.96 - the highest for COMPLEX (referring to complexity as a relative (dis)advantage of the technology to be implemented. These values point to a narrow spread of the values around the mean.

\subsection{Structural equation modelling assessment of measurement model}

Econometric approaches such as SEM are used to confirm a research investigation by testing a priori hypotheses (e.g. Yeh et al., 2010). Using the coordinates extracted by the MCA for the indicators in the previous section, the SEM model estimation was carried out in R-Studio (R-Studio, Boston, MA), making 
Table 2. Multiple correspondence analysis results - descriptive statistics.

\begin{tabular}{|c|c|c|c|c|c|c|c|c|}
\hline \multirow[t]{2}{*}{ MCA indicator } & \multicolumn{8}{|c|}{ Descriptive statistics } \\
\hline & $\bar{n}$ & Mean & Std. Dev ${ }^{1}$ & Min & p25 & Median & p75 & Max \\
\hline \multicolumn{9}{|l|}{ Innovation } \\
\hline $\begin{array}{ll}1 & \text { INNOPROD }\end{array}$ & 283 & 0.00 & 0.82 & -1.05 & -0.54 & -0.54 & 1.00 & 1.00 \\
\hline INNOPROC & 283 & 0.00 & 0.73 & -1.23 & -0.21 & -0.21 & 1.00 & 1.00 \\
\hline INNORG & 283 & 0.00 & 0.82 & -0.61 & -0.61 & -0.61 & 0.95 & 1.64 \\
\hline 4 INNOMARKT & 283 & 0.00 & 0.79 & -2.23 & 0.03 & 0.48 & 0.48 & 0.48 \\
\hline \multicolumn{9}{|l|}{ Internal } \\
\hline CEO & 283 & 0.00 & 0.93 & -1.94 & -0.54 & 0.26 & 0.94 & 0.94 \\
\hline SIZE & 283 & 0.00 & 0.84 & -0.73 & -0.65 & -0.28 & 0.17 & 2.47 \\
\hline RESOURCES & 283 & 0.00 & 0.78 & -1.14 & -0.76 & -0.03 & 0.56 & 1.80 \\
\hline \multicolumn{9}{|l|}{ Technology } \\
\hline 8 GROWTH & 283 & 0.00 & 0.71 & -0.51 & -0.44 & -0.38 & 0.21 & 2.15 \\
\hline 9 NEW MARKETS & 283 & 0.00 & 0.60 & -0.83 & -0.58 & 0.25 & 0.39 & 1.67 \\
\hline 10 QUALITY & 283 & 0.00 & 0.82 & -0.57 & -0.53 & -0.42 & -0.04 & 2.63 \\
\hline 11 COST REDUCT & 283 & 0.00 & 0.81 & -1.72 & -0.23 & 0.43 & 0.45 & 0.49 \\
\hline 12 COMPLIANCE & 283 & 0.00 & 0.84 & -1.23 & -0.54 & -0.06 & 0.49 & 1.50 \\
\hline 13 EMPLOYMENT & 283 & 0.00 & 0.80 & -1.56 & -0.73 & 0.08 & 0.83 & 1.01 \\
\hline 14 TIME INFO & 283 & 0.00 & 0.49 & -1.70 & 0.00 & 0.00 & 0.00 & 1.00 \\
\hline 15 COMPLEX & 283 & 0.00 & 0.96 & -0.67 & -0.54 & -0.40 & -0.28 & 2.33 \\
\hline \multicolumn{9}{|l|}{ Environmental } \\
\hline 16 COMPETITION & 283 & 0.00 & 0.58 & -1.84 & -0.34 & 0.14 & 0.44 & 0.89 \\
\hline 17 SOCIAL & 283 & 0.00 & 0.71 & -1.04 & -0.53 & -0.29 & 0.60 & 1.75 \\
\hline
\end{tabular}

${ }^{1}$ Std. Dev = standard deviation.

use of the partial least squares (PLS) approach. Following the two-step approach by Anderson and Gerbing (1988), we first validate the measurement model, which also allows to check the propositions listed in Section 3 , followed by the analysis of the structural equation model to test the hypotheses defined in that same section.

The validity of the measurement model is based on item reliability, convergent validity, and discriminant validity for reflective constructs, and item reliability and multicollinearity analysis for formative constructs. Checking item reliability led to a simplification of the model. First, the reflective latent construct 'Innovation' uses only three of the four variables: innovation on organisation (INNORG) is excluded because its standardised factor loading is of an opposite sign to that of the other innovation indicators. Second, the following items are not validated because of their small loadings (following Hair et al., 2010, only loadings higher than 0.5 are accepted): CEO support (CEO) and availability of financial resources (RESOURCES) in latent construct L1, and the complexity of adopting the innovation (COMPLEX) and social influence (SOCIAL) in construct L3. Third, for the sake of interpretation, latent construct L2 'advantages of innovation' is split in two, since three of the items show factor loadings of an opposite sign to the others. Hence, we separate latent construct L2a for company growth (GROWTH), enter new markets (NEWMARKETS) and greater quality of goods and services (QUALITY), and latent construct L2b for lower production costs (COST REDUCT), reduced time of response (TIME INFO), environmental, security and regulatory compliance (COMPLIANCE) and maintaining or increasing employment (EMPLOYMENT). Finally, a redundancy analysis (RA) validates all remaining formative variables, since all values are below 5. Table 3 shows the results obtained.

All items have factor loadings or weights above 0.5 (with the nuance of compliance). Convergent validity for reflective constructs requires the average variance extracted (AVE) to be greater than 0.5 (Fornell and Larcker, 1981), which is satisfied. Furthermore, the composite reliability (CR) is above 0.7, providing evidence that the construct for innovation intention satisfies the requirements for reliability (Hair et al., 2010). 
Table 3. Validity of the measurement model. ${ }^{1}$

\begin{tabular}{|c|c|c|c|c|c|c|}
\hline Refle & tive construct & Items & Factor loading & AVE & $\mathbf{C R}$ & \\
\hline I & Innovation intention & INNOPROD & 0.759 & 0.59 & 0.81 & \\
\hline & & INNOPROC & 0.789 & & & \\
\hline & & INNOMARKT & 0.751 & & & \\
\hline Forn & ative construct & Items & Weights & $P$-value & VIF & RA \\
\hline L1 & Ability to innovate & SIZE & 1.000 & 0.000 & NA & \\
\hline $\mathrm{L} 2 \mathrm{a}$ & Advantages of & GROWTH & 0.661 & 0.001 & 2.73 & 1.67 \\
\hline & innovation - markets & NEW MARKETS & 0.592 & 0.001 & 1.90 & 1.29 \\
\hline & & QUALITY & 0.942 & 0.000 & 2.19 & 1.42 \\
\hline $\mathrm{L} 2 \mathrm{~b}$ & Advantages of & COST REDUCT & 0.614 & 0.000 & 1.05 & 1.00 \\
\hline & innovation - internal & COMPLIANCE & 0.425 & 0.001 & 1.61 & 1.17 \\
\hline & & EMPLOYMENT & 0.657 & 0.000 & 1.72 & 1.21 \\
\hline & & TIME INFO & 0.498 & 0.001 & 1.27 & 1.05 \\
\hline L3 & $\begin{array}{l}\text { External restrictions } \\
\text { to innovate }\end{array}$ & COMPETITION & 1.000 & 0.000 & NA & \\
\hline
\end{tabular}

Discriminant validity was not examined, since there is a single reflective construct. Finally, collinearity of formative constructs is checked through the variance inflation factor (VIF): being lower than 3.3 in all cases, it finds no multicollinearity (Kock, 2015).

\subsection{Structural equation modelling analysis}

The goodness of fit for the research model is measured with the path significance of each hypothesis in the research framework, the variance obtained $\left(\mathrm{R}^{2}\right)$, and the predictive sample reuse technique (Stone-Geisser's $\mathrm{Q}^{2}$ ). The results are shown in Table 4 and summarised in Figure 3.

All paths show betas of a coherent sign with the ones anticipated in the hypotheses, with three of the four paths being statistically significant. The firm's ability to innovate is significantly and positively related $(\beta=$ $0.128, P$-value $<0.05$ ) to innovation intention as declared by the firm (supporting hypothesis H1). Nonetheless, of the three organisational variables that were presumed to have a positive impact on innovation through the firm's ability to innovate (CEO support, firm size and availability of financial resources), we can only trace it for firm size (proposition P2).

Potential advantages of the innovation, for which we anticipated a positive impact on innovation intention (hypothesis H2) that stems from seven domains, were actually split in two. Thus, agri-food SMEs in Spain identify the expected benefit of technology innovation in terms of promoting company growth, helping enter new markets, and improving the quality of products (the first set of indicators, in construct L2a). The impact on innovation intention is positive, although not statistically significant ( $\beta=0.055, t$-value 0.848$)$. This implies that agri-food firms innovate in products, processes or marketing in order to increase sales - i.e. because they seek to grow, enter new markets, or increase the quality of their products. Perhaps the pooled nature of the sample - including both farms and food processing firms - may help explain the lack of significance in this L2a estimate. Indeed, factors such as growth and new markets may not be as important for farms relative to processors. 


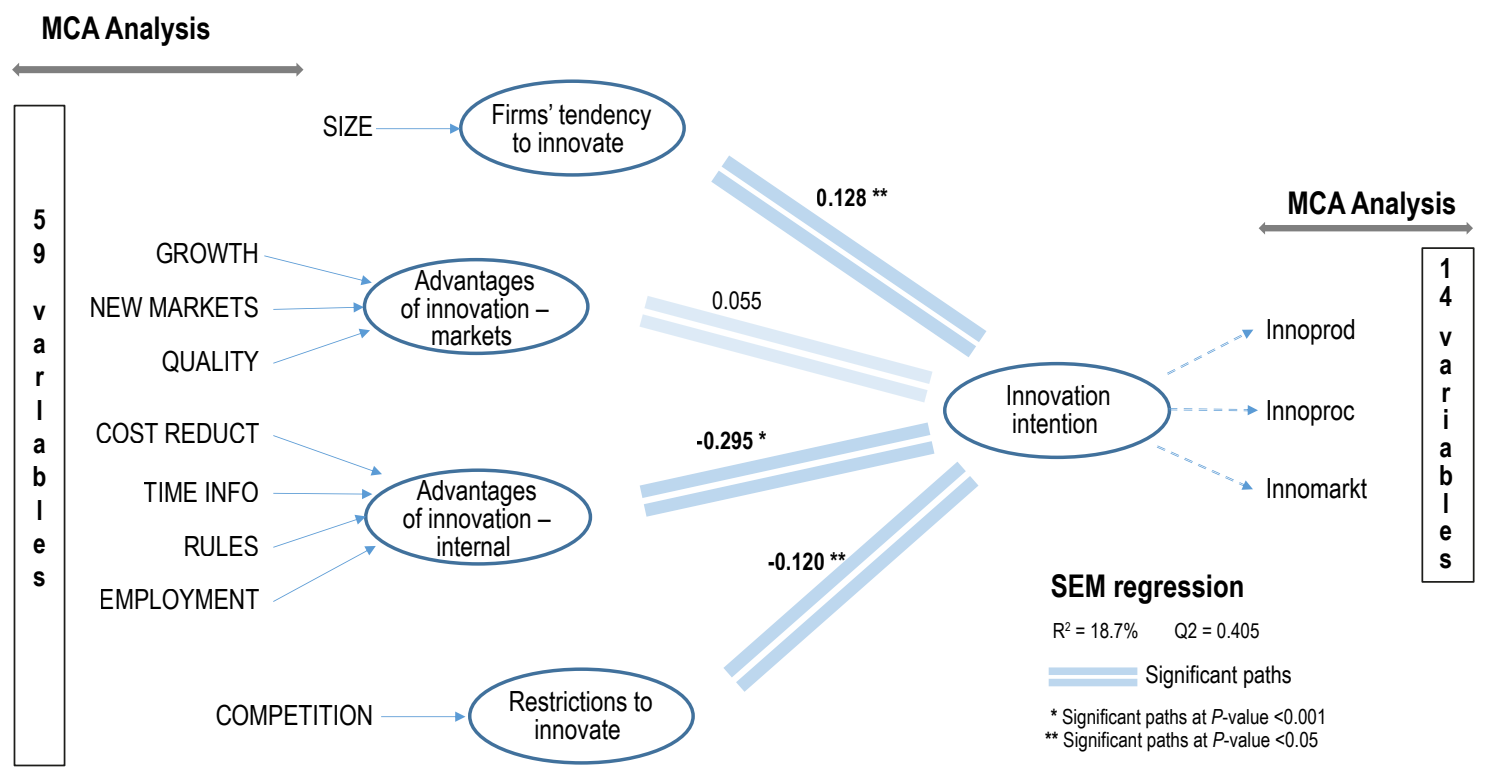

Figure 3. Hypothesised research framework vs tested model.

Table 4. Results of the regression.

\begin{tabular}{llllllc}
\hline Total effect & Estimate & Std. error & $\boldsymbol{t}$-stat. & $\boldsymbol{P}$-value & Effect sizes f $^{\mathbf{2}}$ & CI 95\% \\
\hline I $\sim$ L1 & 0.1277 & 0.0547 & 2.3332 & 0.0196 & 0.0189 & $(0.0245 ; 0.2315)$ \\
I L2a & 0.0545 & 0.0638 & 0.8542 & 0.393 & 0.0024 & $(-0.0379 ; 0.2120)$ \\
I L2b & -0.2953 & 0.0693 & -4.2629 & 0 & 0.0719 & $(-0.4352 ;-0.1556)$ \\
I L2 & -0.12 & 0.0554 & -2.166 & 0.0303 & 0.0146 & $(-0.2168 ;-0.0003)$ \\
\hline
\end{tabular}

Contrariwise, four characteristics of the technology are predicted to have a negative impact on innovation. These are technology innovation in terms of reducing costs, better information exchange and reducing time of response, regulatory and environmental compliance, and in terms of maintaining or increasing employment (the second set of indicators, included in construct L2b). Their impact on innovation intention is negative with sound statistical significance $(\beta=-0.295, P$-value $<0.001)$. This implies that when firms innovate, they declare that they did not so because they were seeking cost reduction, regulatory or environmental compliance, or increasing employment - as these are correlated to 'low' or 'not relevant' answers. The fact that we had to remove innovation on organisation because they were inversely correlated to the other innovation decisions suggest that agri-food firms use this sort of innovation to achieve cost reduction, reduced time of response or regulatory compliance.

Finally, external restrictions to innovate have indeed a significant negative impact on agri-food SMEs innovation intention $(\beta=-0.120, P$-value $<0.05)$, supporting hypothesis $\mathrm{H} 3$. Of the four environmental variables that were presumed to have an impact on innovation (the complexity of innovation adoption, competitive pressure, value chain support/pressure, and social influence), we trace a positive impact on restrictions to innovate (and thus, negative on innovation intention) for COMPETITION, the indicator that merged competitive and value chain pressure (propositions P8 and P9).

The main weakness of the model comes in terms of goodness of fit: $\mathrm{R}^{2}$ is 0.187 , suggesting that only $19 \%$ of the variance in innovation intention by the agri-food firms in Spain can be explained by the data retrieved from PITEC data. Hence, we use an additional measure to test the predictive power of the model. Predictive sample reuse technique, known as the Stone-Geisser's $\mathrm{Q}^{2}$, can be applied as a criterion for predictive relevance 
alternative to the $\mathrm{R}^{2}$ (Henseler et al., 2009). $\mathrm{Q}^{2}>0$ means that the exogenous constructs have predictive relevance for the endogenous construct. We obtain $\mathrm{Q}^{2}=0.405$, suggesting a good predictive relevance for the research model.

\section{Discussion and conclusions}

We studied the main drivers of innovation by agri-food SMEs by analysing the innovation intention of a set of Spanish firms based in rural areas where socioeconomic indicators are weak. Using TOE as conceptual framework, we performed an MCA PLS-SEM analysis combined to overcome data limitations, to identify the relevant factors among 63 indicators in four domains, including innovation decisions, organisational, technological and environmental features.

The results confirm most of the prior hypotheses, according to the literature of determinants of innovation by firms outside rural areas. First, the capacities and financial resources of the agri-food firms are significantly and positively related to the firms' intention to innovate. However, only firm size - measured with revenues, number of employees and years since the launch of the company - was found to be representative of the ability to innovate. CEO support and direct measures of availability of internal and external sources of finance had to be discarded based on item reliability in the assessment of the SEM model.

Second, the impact of perceived advantages of innovation on decisions to innovate provide the most insightful results. Firms innovate to offer a wider range of products and increase market share (firm growth), getting access to new markets and costumer segments (new markets), and improving the quality of products and flexibility in production (quality) - although the overall impact of these factors combined was not found to be statistically significant. However, other potential advantages of innovation, including lowering unit costs (cost reduction), regulatory compliance on environment, health, and security (compliance), maintaining or increasing total and qualified employment (employment), and improving time of response and information exchange (time info), have a significant negative impact on agri-food SMEs innovation.

Third, environmental restrictions to innovate are also found to have a significant negative impact on agrifood SMEs innovation intention. Here, significant environmental restrictions are summarised in a single construct (competition), which is a mix of competitive pressure by peer competitors and the bargaining power of other agents in the value chain.

In other instances, our results are inconclusive due to the quality of information available. Thus, innovation decisions on organisation (management systems, external relationships, etc.) had to be excluded from the analysis for statistical reasons. In addition, because of low item reliability - and beyond the two domains on internal characteristics already outlined - one technological domain (the complexity of the technology to be implemented) and one environmental domain (social influence, summarising the relationship with universities, public agencies, technology centres and others) had to be excluded as well. Hence, open questions by previous research, such as marketing abilities being important to overcome financial restrictions (Banterle et al., 2011) and marketing innovation related to firms' ICT experience (Peón and Martínez-Filgueira, 2020) and social factors (Hinrichs et al., 2004) are left without response.

The external validity of this research would have relevant implications in terms of public policy recommendations - they follow in order. First, smaller and younger firms would face more restrictions to innovate. This is a common result observed by other studies of agri-food innovation in Spain (Corchuelo and Mesías, 2017; Fearne et al., 2013), which corroborates the need for cooperation between these firms, and public support for them. In any case, this is already a priority observed both by authorities and practitioners in Spain: the Spanish Ministry of Agriculture recommends intensifying public funding for cooperative business R\&D projects, together with universities and research organisations (MAGRAMA, 2015), and optimising synergies between companies in their export, logistical and commercial efforts are seen essential (KPMG, 2015). 
Second, agri-food SMEs operating in rural areas would be stating clear that their main objectives are growth, finding new markets or customer niches, and improving the quality of their products (presumably, to make them easier to be sold). In those instances, they feel innovation can help, and public policies should contribute. This is good news for public policy: in the aforementioned strategic plan, the Spanish Ministry of Agriculture highlights the first and essential need to ensure that market demand acts as a driving force for innovation. Firms in Spain seem to be aware of that. However, this might not be a valid result elsewhere, as it shows a dependence on external demand for industry development. To achieve those targets, greater involvement of SMEs in R\&D activities is needed: internal R\&D expenditure in agriculture in Spain represents only 5.4\% of total innovation expenditure. Moreover, the modernisation of the production process through investment in capital goods continues to be the main path to improve competitiveness (Alarcón and Sánchez, 2013). However, there is a strong dependence on public funding, which accounts for $59.1 \%$ of funding, compared to $33.9 \%$ from the business sector and 7\% from higher education, not-for-profit organisations, and foreign funds (MAGRAMA, 2015).

Third, on the contrary, environmental compliance and maintaining or increasing employment do not seem to be reasons for these firms to innovate. Consequently, public policies should be oriented to facilitate these two essential objectives of regional development. These results show some distinctive behaviour of innovation in Spain compared to the extant research in other regions. Indeed, we could not trace the impact of classic determinants, such as a restricted access to capital, or disaggregating the contributors in the value chain though in both cases that was due to not meeting the methodological requirements.

We must emphasise the limitations of this research. First, despite obvious, it is worth noting that the survey results provide information about firms' managers claiming that they are innovative (that is, we are testing innovation intention); whether these firms do innovate is unknown. Second, the limited impact in terms of variance explained demands caution. Although the predictive sample reuse technique we tested for robustness suggests a good predictive relevance of the research model, further research is needed. This limitation is related to the low quality of some data that the MCA-PLS-SEM strategy allowed to filter out. Third, where the model did not show some classic results observed in the literature, this might be attributable to some extent to the quality of data available through the PITEC questionnaires. Despite these limitations, the topic reveals to be a promising area for future research.

\section{Supplementary material}

Supplementary material can be found online at https://doi.org/10.22434/IFAMR2021.0015

Table S1. Variables and descriptive statistics.

Table S2. Cronbach alpha.

\section{Acknowledgements}

David Peón acknowledges financial support by Agencia Estatal de Investigación (Ministerio de Ciencia, Innovación y Universidades) under research project with reference RTI2018-100702-B-I00, co-funded by the European Regional Development Fund (ERDF/FEDER).

\section{References}

Adamkolo, M.I., M.S. Hassan and S. Yusuf. 2016. Determinants of information technology adoption among Malaysian farm-based enterprises. Pertanika Journal of Social Sciences and Humanities 24(4): 1753-1765.

Agwu, A.E., J.N. Ekwueme and A.C. Anyanwu. 2008. Adoption of improved agricultural technologies disseminated via radio farmer programme by farmers in Enugu State, Nigeria. African Journal of Biotechnology 7: 1277-1286. 
Alarcón, S. and M. Sánchez. 2013. External and internal R\&D, capital investment and business performance in the Spanish agri-food industry. Journal of Agricultural Economics 64(3): 654-675.

Ali, J. 2012. Factors affecting the adoption of information and communication technologies (ICTs) for farming decisions. Journal of Agricultural \& Food Information 13(1): 78-96.

Alvarez, J., and P. Nuthall. 2006. Adoption of computer-based information systems: the case of dairy farmers in Canterbury, NZ, and Florida, Uruguay. Computers and Electronics in Agriculture 50: 48-60.

Anderson, J.C. and D.W. Gerbing. 1988. Structural equation modelling in practice: a review and recommended two-step approach. Psychological Bulletin 103(3): 411.

Arias, P., S. Alarcón and M. Botey. 2016. La caracterización a través del análisis factorial de las empresas agroalimentarias según sus obstáculos a la innovación. Economía Industrial 400: 139-149.

Avermaete, T., J. Viaene, E.J. Morgan and N. Crawford. 2003. Determinants of innovation in small food firms. European Journal of Innovation Management 6(1): 8-17.

Baker, J. 2011. The technology-organization-environment framework. In Y. Dwivedi, M. Wade and S. Schneberger (eds.) Information systems theory: explaining and predicting our digital society. Springer, New York, NY, USA, pp. 231-246.

Banterle, A., A. Cavaliere, L., Carraresi and S. Stranieri. 2011. Innovativeness in food small business: what is its relationship with marketing? Agricultural Economics 57(10): 474-483.

Barbut, L., 2009. L'évaluation ex post du PDRN: un regard instructif sur le passé pour améliorer l'avenir. Notes et Études Socio-Économiques 33: 7-39.

Batterink, M.H., E.F.M. Wubben and S.W.F. Omta. 2006. Factors related to innovative output in the Dutch agrifood industry. Journal on Chain and Network Science 6(1): 31-44.

Battor, M. and M. Battor. 2010. The impact of customer relationship management capability on innovation and performance advantages: testing a mediated model. Journal of Marketing Management 26(910): 842-857.

Besser, T.L. and N.J. Miller. 2013. Community matters: successful entrepreneurship in remote rural US locations. Entrepreneurship and Innovation 14(1): 15-27. https://doi.org/10.5367/ijei.2013.0104

Blanchard, P., J.P. Huiban, A. Musolesi and P. Sevestre. 2013. Where there is a will, there is a way? Assessing the impact of obstacles to innovation. Industrial and Corporate Change 22: 679-710.

Castillo Valero, J.S. and M.C. García Cortijo. 2016. La innovación en la industria agroalimentaria y sus determinantes estructurales y territoriales: el caso de la crisis económica en Castilla-La Mancha. In: Proceedings of the XI Iberian Conference on Rural Studies International Conference 'the smart and inclusive development in rural areas'. October 13-15, 2016. Universidade de Trás-os-Montes e Alto Douro, Vila Real, Spain, pp. 489-503.

Corchuelo, B. and F.J. Ferreiro. 2019. Agri-food industry in Extremadura: obstacles to innovation, willingness to innovate, and demanded public actions. Revista de Investigaciones Regionales 45: 191-199.

Corchuelo, B. and F.J. Mesías. 2017. Disposición a innovar y competitividad en la agroindustria extremeña. ITEA Información Técnica Económica Agraria 113(2): 176-191.

Corchuelo, B., P.E. López Salazar and C. Sama-Berrocal. 2020. Determining factors of innovative performance: case studies in Extremaduran agri-food companies. Sustainability 12(21): 9098.

Díaz-Pichardo, R., P.S. Sánchez-Medina and C. García De La Torre. 2017. Explaining inequality within the bop: urban vs rural. Journal of Developmental Entrepreneurship 22(3): 1750016.

Erjavec, E. and J. Rickson. 2016. Identification of current role of innovation and knowledge policy in agriculture and rural development with brief reference to strengths and weaknesses. In: Cork 2.0 Conference on Rural Development. 5 September 2016. Cork, UK. Available at: https://ec.europa.eu/ agriculture/sites/ agriculture/files/events/2016/rural-development/ws3-erjavec_en.pdf

Erjavec, K., E. Erjavec and L. Juvančič. 2009. New wine in old bottles: critical discourse analysis of the current common EU agricultural policy reform agenda. Sociologia Ruralis 49(1): 41-55.

European Commission. 2016a. Workshop 1: Jobs, growth and investment in the wider rural economy. In: Cork 2.0 Conference on Rural Development. 5 September 2016. Cork, UK. Available at: https://www.europanu.nl/id/vk5ia4sdf1w4/agenda/cork_2_0_european_conference_on_rural?ctx=vg9pir5eze8o\&tab=1 
European Commission. 2016b. The Cork 2.0 Declaration 2016: 'a better life in rural areas'. In: Cork 2.0: European Conference on Rural Development. 5 September 2016. Cork, UK. Available at: http:// ec.europa.eu/agriculture/events/rural-development-2016_en.htm

European Commission. 2021. Horizon Europe strategic plan (2021-2024). Directorate-General for Research and Innovation, European Commission, Brussels, Belgium. Available at: https://ec.europa.eu/info/ research-and-innovation/funding/funding-opportunities/funding-programmes-and-open-calls/horizoneurope/strategic-plan_en\#the-first-horizon-europe-strategic-plan-2021-2024

Eurostat. 2020. Territorial typologies manual - urban-rural typology. EU, Brussels, Belgium.

Fearne, A., J.M. García-Álvarez-Coque, T. López-García and S. García. 2013. Innovative firms and the urban/rural divide: the case of agro-food system. Management Decision 51(6): 1293-1310.

Firlej, K., A. Kowalska and A. Piwowar. 2017. Competitiveness and innovation of the Polish food industry. Agricultural Economics 63(11): 502-509.

Fornell, C. and D. Larcker. 1981. Structural equation models with unobservable variables and measurement error. Journal of Marketing Research 18(1): 39-50.

García Álvarez-Coque, J.M., T. López-García and M. Sánchez. 2013. Territory and innovation behaviour in agri-food firms: does rurality matter? New Medit: a Mediterranean Journal of Economics, Agriculture and Environment 3: 2-10.

Greenacre, M. 2016. Correspondence analysis in practice, $3^{\text {rd }}$ edition. CRC Press, Boca Raton, FL, USA.

Hair, J.F., W.C. Black, B.J. Babin, R.E. Anderson and R.L. Tatham. 2010. Multivariate data analysis, $7^{\text {th }}$ edition. Prentice Hall, Upper Saddle River, NJ, USA.

Henseler, J., C. Ringle and R. Sinkovics. 2009. The use of partial least squares path modelling in international marketing. Advances in International Marketing 20: 277-320.

Hinrichs, C.C., G.W. Gillespie and G.W. Feenstra. 2004. Social learning and innovation at retail farmers' markets. Rural Sociology 69(1): 31-58.

Johannessen, J.-A., B. Olsen and G.T. Lumpkin. 2001. Innovation as newness: what is new, how new, and new to whom? European Journal of Innovation Management 4(1): 20-31.

Kock, N. 2015. Common method bias in PLS-SEM: a full collinearity assessment approach. International Journal of e-Collaboration 11(4): 1-10.

KPMG. 2015. Retos y perspectivas de la industria de alimentación y bebidas en España. KPMG España, Madrid, Spain. Available at: assets.kpmg/content/dam/kpmg/pdf/2015/07/retos-perspectivas-industriaalimentacion-espana.pdf

Le, S., J. Josse and F. Husson. 2008. FactoMineR: an R package for multivariate analysis. Journal of Statistical Software 25(1): 1-18. https://doi.org/10.18637/jss.v025.i01

Maduku, D.K., M. Mpinganjirab and H. Duh. 2016. Understanding mobile marketing adoption intention by South African SMEs: a multi-perspective framework. International Journal of Information Management 36: 711-723.

Ministerio de Agricultura, Pesca y Alimentación (MAGRAMA). 2015. Programa Nacional de Innovación e Investigación Agroalimentaria y Forestal. Ministerio de Agricultura, Pesca y Alimentación, Madrid, Spain.

Mirzaei, O., E.T. Micheels and A. Boecker. 2016. Product and marketing innovation in farm-based businesses: the role of entrepreneurial orientation and market orientation. International Food and Agribusiness Management Review 19(2): 99-130.

Organisation for Economic Co-Operation and Development (OECD). 2012. April 2012 Joint OECD/G20 GPFI Special Event on SME finance. OECD \& G20 Global Platform for Financial Inclusion. OECD, Paris, France. Available at: https://www.oecd.org/cfe/smes/50112013.pdf

Organisation for Economic Co-Operation and Development (OECD). 2018. Enhancing SME access to diversified financing instruments. Discussion paper, SME Ministerial Conference. 22-23 February 2018. Mexico City, Mexico. Available at: https://www.oecd.org/cfe/smes/ministerial/documents/2018SME-Ministerial-Conference-Plenary-Session-2.pdf

Peón, D. and X.M. Martínez-Filgueira. 2020. Determinants of investing in innovative activities by agri-food and KIBS firms in rural areas: an exploratory analysis. Journal of Small Business Management 58(6): 1155-1186. https://doi.org/10.1111/jsbm.12513 
Peón, D., X.M. Martínez-Filgueira and E. López-Iglesias. 2020. Productive vs. residential economy: factors behind the recovery of rural areas in socioeconomic decline. Revista Galega de Economía 29(2): 1-30. https://doi.org/10.15304/rge.29.2.6744

Quinn, B., L. McKitterick, R. McAdam and M. Brennan. 2013. Innovation in small-scale retailing. International Journal of Entrepreneurship and Innovation 14(2): 81-93.

Ramayah, T., N.S. Ling, S.K. Taghizadeh and S.A. Rahman. 2016. Factors influencing SMEs website continuance intention in Malaysia. Telematics and Informatics 33: 150-164.

Renski, H. 2009. New firm entry, survival and growth in the United States: a comparison of urban, suburban and rural areas. Journal of the American Planning Association 75(1): 60-77.

Rodriguez, M., D. Doloreux and R. Shearmur. 2017. Variety in external knowledge sourcing and innovation novelty: evidence from the KIBS sector in Spain. Technovation 68: 35-43.

Sehnem, S., D. Roman, A. Sehnem and N.S. Machado. 2016. Competitive advantage in a credit cooperative: the role of resources. International Business Management 10(15): 2768-2779.

Sonawane, M.B. 2014. Entrepreneurship (entrepreneurial mind) in emerging economies. Journal of Business Management and Social Sciences Research 3(2): 24.

Tampien, J. 2016. Locally sourced capital for small businesses in rural communities. Journal of Extension 54(5): 16.

Thornhill, S. 2006. Knowledge, innovation and firm performance in high- and low-technology regimes. Journal of Business Venturing 21(5): 687-703.

Tiffin, R. and K. Balcombe. 2011. The determinants of technology adoption by UK farmers using Bayesian model averaging: the cases of organic production and computer usage. The Australian Journal of Agricultural and Resource Economics 55: 579-598.

Turland, M. and P. Slade. 2020. Farmers' willingness to participate in a big data platform. Agribusiness 36(1): 20-36.

Yeh, P.-H., H. Zhu, M.A. Nicoletti, J.P. Hatch, P. Brambilla and J.C. Soares. 2010. Structural equation modelling and principal component analysis of gray matter volumes in major depressive and bipolar disorders: differences in latent volumetric structure. Psychiatry Research 184(3): 177-185.

Zouaghi, F.E. and M. Sánchez. 2016. Has the global financial crisis had different effects on innovation performance in the agri-food sector by comparison to the rest of the economy? Trends in Food Science and Technology 50: 230-242. 
